\title{
換気回路網における理論解の多様性に関する研究 STUDY ON THE VARIETY OF THEORETICAL SOLUTIONS OF VENTILATION NETWORK
}

\author{
新田勝 通* \\ Katsumichi NITTA
}

\begin{abstract}
On a ventilation system affected by the buoyancy forces, different kinds of ventilation, such as several combinations of flow directions, flow rates or room temperatures, may occur in spite of the same setting of heat supply or temperature and same wind force. Theoretical studies on the variety of ventilation may not have been reported, although an experimental verification has been shown.

On this paper, the creation of the variety of ventilation is verified to be caused by the buoyancy terms using the network model, and the kinetic energy that acts on the onside atmosphere by the ventilation system is adopted as an index of the occurrence frequency.

The smoke eject problem in fire is studied so the variety of ventilation may cause the dangerous situation. The numerical calculations show that owing to the variety of ventilation the effects of natural smoke vents or fans become ineffective as the case may be, especially in the underground compartments with ventilators.
\end{abstract}

Keywords: Ventilation, Variety solutions, Buoyancy force, Kinetic Energy, Smoke vents, Underground compartment, Ventilation calculation

換気、多様性、浮力、仕事、排煙口、地下街、換気計算

\section{1.はじめに}

浮力の作用する換気系において、供給熱設定あるいは 室温設定、外気風圧等の与条件が同一であっても異なる 換気経路（換気方向、換気量、室温）が出現する。この 換気の多様性の存在については実験での検証例" もある が、理論的研究はその報告を見ない。

本研究は、換気回路網モデルが適用できる換気系を対 象として、運動の式、熱収支式の組み合わされた基礎式 における浮力項によって換気の多粎性が存在する事を先 ず指摘し、換気系が外部に成す力学的エネルギー(仕事) の大きさをもって生起頻度の指標として捉え、簡単な閉 回路換気系でもって多様性の具体例を示す。

次いで、換気の多様性が危険性に結びつく可能性のあ る、火災時の排煙問題を取り上げ自然排煙口の設置位置 あるいは排洷ファン風量の效果が全くあるいは十分に期 待できない場合が生じることを換気計算の数值計算結果 を用いて検討する。

\section{2. 回路網による換気モデル}

本論では、室内での圧力損失が無視でき、室温を接点 で代表し、開口での圧力損失による抵抗、および浮力な らびに外壁風圧に関する起電力からなる枝でもって接点 を結合する「換気回路網」によるモテル化が可能な換気 を扱う。図1に例を示す。回路を表現する方法として、 結合行列 $[I]$ と開口を連結する独立閉回路であるループ 行列 $[L]$ を用いる。

杞号 :

$\alpha A$ : 開口有効面積、 $C_{\mathrm{p}}$ : 空気の比熱、

$[F]$ : 温度変換行列、 $G$ : 質量流量、 $g$ : 重力加速度、 $H, h$ : 開口高さ、 $[I]:$ 結合行列、 $[L]:$ 閉回路行列、 $p$ : 静圧、 $\Delta p_{w}$ : 風圧差、Q : 発熱量、 $T$ : 絶対温度、 $U$ : 熱コンダクタンス、 $W$ : 仕事、 [ ] ? $]^{\mathrm{T}}$ : 転置行列、 []$^{-1}$ : 逆行列、[[ ]] : 対角化行列、\{ $\}:$ ベクトル、 $\theta$ : 温度（外気温基準）、 $\rho:$ 密度。

添字; 0 : 外気、 : 室内、 $\mathrm{j}, \mathrm{k}$ : 開口、 : 閉回路
* 京都工芸䋐維大学工芸学部造形工学科 助教授・ 工博
Assoc. Prof., Dept. of Architecture and Design, Kyoto Institute of Technology, Dr. Eng. 
(1) 式は図 1 の $[I] 、[L]$ である。ここで、図の任意に 設定した換気方向に従って行列の値を $\pm 1 、 0$ と定める。

(1) (2) (3) (4) (5)

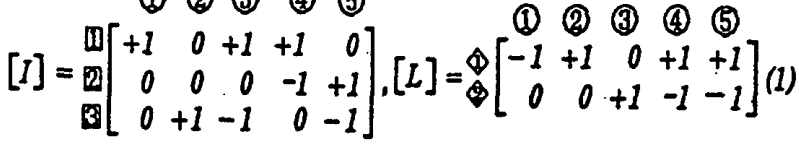

$M$ 室 $N$ 開口の系では独立なループは $L(=N-M)$ 個ある。

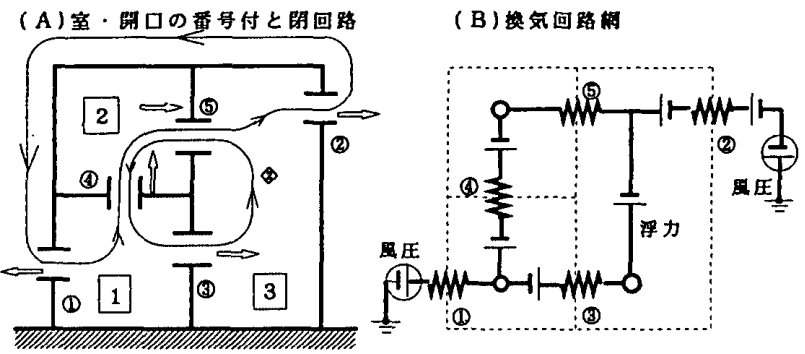

図 1. 換気回路網モデル

\section{3. 換気の基礎式}

結合行列 $[I]$ 、閉回路行列 $[L]$ を用いた換気回路網での 基礎式は次式となる。ここでは、断りのない限り浮力と 風力による自然換気のみの場合を扱う。

$$
\left\{\begin{array}{l}
{[L]\left(\{\Delta p\}+\llbracket h \rrbracket[I]^{T}\{\Delta \dot{\rho}\}_{g}-\left\{p_{w}\right\}\right)=\{0\}} \\
\{\Delta p\}=\frac{1}{2 \rho_{0}} \llbracket \frac{1}{\alpha A^{2}} \rrbracket\left\{G^{2}\right\} \\
\{\Delta \dot{\rho}\}=\frac{\rho_{0}}{T_{0}}\{\dot{\theta}\} \\
C_{D}[I] \llbracket G \rrbracket\{\theta\}-[U]\{\dot{\theta}\}=\{\dot{Q}\} \\
\{\theta\}=[F]\{\dot{\theta}\}
\end{array}\right.
$$

(2)〜（6）式はそれぞれループの圧力収支式（閉路方 程式）、開口特性式、状態方程式、熱収支式および開口 温度と室内温度の関係式を表す。 ${ }^{2}(2)$ 式は $L$ 列べク トルであり、 $[L]_{L N}$ が正方行列であり逆行列が存在する 場合にのみ式より $[L]$ を取り除くことができるが、一 般に $L<N$ であり左辺（）内の $N$ 列べクトルを零と置く ことはできない。 $[F]$ は開口温度を室温より求めるブー ル代数による写像行列であり、換気経路が異なれば行列 要素は異なる値を取る。なお、換気の多様性の説明の便 宜上( 3 )、(4)式において Boussinesq 近似を用いている。 各室における流量収支式（節点方程式）は(7)式とな

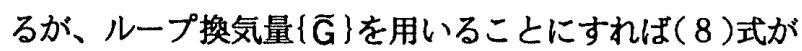
成立ちまた $[I]$ と $[L]$ は $(9)$ 式の関係があるため流量収支 式 ( 7 )は常に満足するので本論では（7)式を用いない。

$$
\left\{\begin{array}{l}
{[I]\{G\}=\{0\}} \\
\{G\}=[L]^{T}\{\widetilde{G}\} \\
{[I][L]^{T}=[0]}
\end{array}\right.
$$

言い換えれば Kirchhoffの第 1 法則ではなく第 2 法則を 適用しており、室内圧は物理量として陽に登場しない。

\section{4. 換気経路の多櫒性存在の一般䄖的検时}

換気計算は、建物開口での空気の流れ力向、流量を定 めるだけでなく、供給熱設定の室があればその室温を、 熱亡流れの組み合わせの現象から求めなければならない。

本節では、与条件が全く同一の建物に対して集中定数 系の換気回路網モデルで近似し得るとして、「換気経路」 すなわち換気量、換気方向、室温あるいは供給熱が異な る状態が複数存在することを基礎式( 2 ) （6)式を用い て定性的に示し、外部に成す仕事を指標としてその生起 頻度を考察する。 $5 、 6$ 節においてその具体例を示す。

\section{4-1．室温度設定の棫合}

多数室全ての室温 $\{\hat{\theta}\}$ が設定される場合は、外気との 密度差 $\{\Delta \hat{\rho}\}$ 屯既知量であり、(2)、（3)式より圧力損 失 $\{\Delta p\}$ を消去して $(10)$ 式となり、 $\{G\}$ の係数および右 辺は既知量であるから右辺大括弧内が非負値であれば換 気量 $\left\{G^{2}\right\}$ が一つ求められる。Gjの正負は換気方向が 流量収支を満足するかどうかで定められる。

$\left.\frac{1}{2 \rho_{0}}[L] \llbracket \frac{1}{\alpha A^{2}}\right]\left\{G^{2}\right\}=[L]\left(\left\{p_{w}\right\}-\llbracket h \rrbracket[I]^{r}\{\Delta \dot{\rho}\}_{g}\right)(10)$

一部の室のみ温度設定であり、他室に供給熱設定室が 含まれる場合、次節 4-2で示すように換気量 $\{G\}$ に複 数解を生じ得る可能性がある。

\section{4-2. 供給熱設定の场合}

供給熱が設定される場合は室温は熱収支式 (5)を満足 しなければならない。実際の建物では温度制御付きで室 温を一定に維持する以外の室はすへてて供給熱設定である。 発熱の無い廊下、シャフトなども零の供給熱設定である。 全室供給熱設定とすると、基礎式(5)、（6）上り

$$
\{\hat{\theta}\}=\left[C_{D}[I]^{T} \llbracket G \mathbb{} \mid[U]\right]^{-1}\{\hat{Q}\}
$$

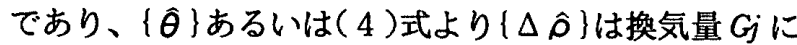
関して $1 /(a G j+b)$ の形の関数となる。(10)式に代入して 分母を払うことにより左辺の $G{ }^{2}$ の項の存在から $G j に$ ついての 3 次の多項式展開となり、また $L$ 個の独立閉 回路が存在するため与条件 $\{\hat{Q}\} 、\{p w\} 、\{h\} の$ 値によっ ては最大 $3 L$ の複数解が存在し得る。

なお Boussinesq 近似ではなく厳密に密度が温度により 変化する場合は、(3)、(4)式から、

$$
\left\{\begin{array}{l}
\left.\{\Delta p\}=\frac{1}{2 \rho_{0}} \llbracket \frac{T_{0}+\dot{\theta}}{T_{0}}\right] \llbracket \frac{1}{\alpha A^{2}} \rrbracket\left\{G^{2}\right\} \\
\left.\{\Delta \dot{\rho}\}=\rho_{0} \llbracket \frac{\dot{\theta}}{T_{0}+\dot{\theta}}\right\rfloor
\end{array}\right.
$$


であるから、(10)式に対応する式は、

$$
\begin{aligned}
\frac{1}{2 \rho_{0}} & {[L]\left\|\frac{T_{0}+\hat{\theta}}{T_{0}}\right\| \llbracket \frac{1}{\alpha A^{2}} \rrbracket\left\{G^{2}\right\} } \\
& =[L]\left(\left[p_{W}\right\}-\llbracket h \rrbracket[I]^{T} \rho_{0} \| \frac{\hat{\theta}}{T_{0}+\hat{\theta}} \rrbracket g\right)
\end{aligned}
$$

となり、 $\hat{\theta}$ が $1 /(a G j+b)$ の関数であるため、換気量 $G j$ についてみれば 5 次の多項式に展開出来る。従って最大 5 個の、全換気系では $5 L$ の複数解が存在し得る。

\section{4-3．外部に成す仕事による多檬な換気系の睐価}

与条件が同じでも複数の換気経路が生じることを前節 で示したが、複数の状態が存在し得る場合いずれの換気 経路が出現性が高いかの問題を本節にて検討する。

発熱量、外気風等に外乱が生した後に元の外部条件に 復㷌したとき確率的に、すなわち独立試行を繰り返した とき、生起する頻度（无度）でもってこれを評価出する のが適切であろう。しかし換気の定常基礎式系のみから 直接に生起頻度の理論的検討は出来ず、本論では、建物 外皮を検查面として、外部より投入される同一の熱およ び同一の風圧に対し換気システムが外部に戻すエネルギ 一が大きくなる換気状態ほど生起頻度が高くなるものと みなして、このエネルギーを評価指標とする。

熱と力学のエネルギーの内、熱的エネルギーは本モテ ルでは(5)式に示したように外部より投入された熱は全 て外部へ放出されているのでエネルギーの指標に用いる ことは出来ず、外部に成す「仕事」すなわち力学的エネ ルギーのみを評価する。ここで(2)式は建物外部でのエ ネルギーの搪散、浮力も含んだ収支式であり建物外皮を 検查面とした「仕事」を表現するものではない。また (5)式では開口での圧力損失による仕事から熱への変換 分は通常の換気では供給熱に比へてて十分小さく無視する。

任意の外皮開口での力学的エネルギーは以下のように して求める。開口で外気が流入したとすると開口を通る 流管に対し Bernoulli の定理より、

$$
p_{W}-\rho_{0} g h=\dot{p}-\dot{\rho} g h+\frac{\rho_{0}}{2}\left(\frac{G}{\alpha \rho_{0} A}\right)^{2}
$$

この流れのエネルギー（撖密には仕事率）W は(12) 式に $G / \rho$ 。を乗じた值である。右辺、左辺いずれの側を 用いても良いので、室内圧令を陽に含まない側を用いる。 流出の場合も同様である。流入開口 $\mathrm{j}$ ，流出開口 $\mathrm{k} に お ~$ ける仕事および建物全体での仕事は次式となる。

$$
\begin{aligned}
& \left(W_{\text {in }}\right)_{j}=\frac{\left|G_{j}\right|}{\rho_{0}}\left(p_{w}-\rho_{o g} g\right)_{j} \\
& \left.\left(W_{\text {oxk }}\right)_{k}=\frac{\left|G_{k}\right|}{\dot{\rho}_{k}}\left(\frac{\dot{\rho}_{k}}{2}\left(\frac{G_{k}}{\alpha \dot{\rho}_{k} A}\right)^{2}+p_{W}-\rho_{o g} h\right)\right\}_{k}
\end{aligned}
$$

$$
W=\sum_{j, k}^{\text {外皮問口 }}\left(W_{\text {oxt }}\right)_{k}-\left(W_{\mathrm{it}}\right)_{j}
$$

行列表現すれば、

$W=\left\{I_{\alpha \alpha t}\right\} 1 / 2 \llbracket 1 /(\alpha \dot{\rho} A)^{2} \rrbracket \llbracket|G|^{2} \rrbracket$

$+\left(\left\{I_{\text {out }}\right\} \llbracket 1 / \dot{\rho} \rrbracket-\left\{I_{\text {in }}\right\} 1 / \rho\right) \llbracket|G| \rrbracket\left(\left\{\phi_{w}\right\}-\rho_{o} g\{h\}\right)$

ここで $\{$ Iint $\} 、\{$ Iout $\}$ は外気との換気の有無を表す $N$ 列 ベクトルである。例えば $\{$ Iint $\}=\{0,1,0\}$ 、 $\{$ Iout $\}=\{0,0,1\}$ は 第 1 開口は外皮に無く、第 2 開口からの流入、第 3 開口 からの流出を示す。

\section{5.一閉回路系の換気経路の多模性}

本節では最も簡単な換気系を例としてあげ、換気経路 の多様性出現の状態をより具体的に示す。

図 2(A)に示すような開口の配置では一閉回路でもっ て全開口を結ぶことができ 1 ループ換気系と呼ぶことに する。この換気系での換気経路の多様性を示す。
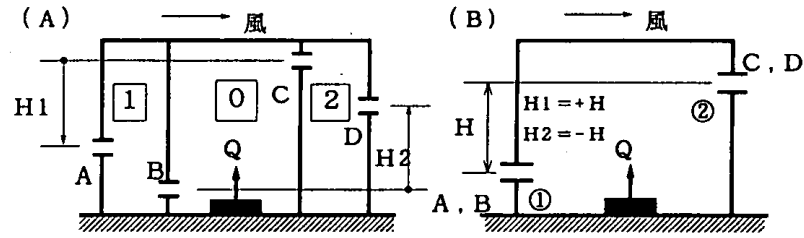

図２１ループ換気系の例（(B)は(A)の特殊例）

換気方向は時計回り $(A \rightarrow B \rightarrow C \rightarrow D \rightarrow A)$ と反時計回り $(D \rightarrow C \rightarrow B \rightarrow$ $A \rightarrow D)$ の 2 種が存在し得る。換気量は時計回りを $G>0$ 、反 時計回りにG<0を割り当てることにする。図 $2(\mathrm{~A})$ の うに中央の室で発熱あるいは室温設定があるとし、他の 2 室は零の供給熱設定とする。室内の圧力損失を無視し て、Kirchhoff の第 2 法則より次式が得られる。

・時計回りの換気が生じる場合 :

$$
\frac{G^{2}}{2 \dot{\rho}} \frac{1}{\alpha A_{1}{ }^{2}}+\frac{G^{2}}{2 \rho_{0}} \frac{1}{\alpha A_{2}{ }^{2}}=g \Delta \dot{\rho} H_{1}-\Delta p w
$$

・反時計回りの換気が生じる場合：

$$
\frac{G^{2}}{2 \rho_{0}} \frac{1}{\alpha A_{1}{ }^{2}}+\frac{G^{2}}{2 \hat{\rho}} \frac{1}{\alpha A_{2}{ }^{2}}=g \Delta \dot{\rho} H_{2}+\Delta p_{W} \text { (17) }
$$

ここで、

$$
\left.\begin{array}{rl}
\Delta \dot{\rho}=\rho_{0}-\dot{\rho}, \quad \Delta p_{W}=p_{W A}-p_{W D} \\
H_{1}=h_{A}-h_{C}, H_{2}=h_{D}-h_{B}, \\
\frac{1}{\alpha A_{1}^{2}}=\frac{1}{\alpha A_{A}^{2}}+\frac{1}{\alpha A_{B}^{2}}, \frac{1}{\alpha A_{2}^{2}}=\frac{1}{\alpha A_{C}^{2}}+\frac{1}{\alpha A_{D}^{2}}
\end{array}\right\}
$$


熱収支式、状態方程式は、

$$
\begin{aligned}
\dot{Q} & =\left(C_{0}|G|+U\right) \dot{\theta} \\
\dot{\rho} & =\frac{T_{0}}{T_{0}+\dot{\theta}} \rho_{0},\left(\Delta \dot{\rho}=\frac{\dot{\theta}}{T_{0}+\dot{\theta}} \rho_{0}\right)
\end{aligned}
$$

図 2 (B)に示す 2 開口単室換気では、 $H_{1}=H_{1} H_{2}$ $=-H$ と置くことによって(16)、(17)式が適用できる。

\section{1 全室温度設定の域合}

全室の室温が設定されている場合は、密度も既知であ るから(16)、(17)式右辺が非負值であればそれぞれ解を 有する。図 $2(\mathrm{~A})$ 換気系にて、与条件 $\Delta p w / g \Delta \hat{\rho} に$ 対する換気量 $G$ の変化を図 3 に示す。縦軸 $G$ は開口面 積、密度によってスケールは変わる。図 2 の相対的開口 高さ $H_{1} 、 H_{2}$ の違いによって唯一解、2つの解および解 なし(物理的には換気量零の解)が得られる。ここで開口 $\mathrm{A}$ とBの高さの相対的差は基礎式に現れず換気に関与し ないことがわかる。図2(B)のような 2 開口の場合には $H_{1}=-H_{2}$ であり図 3 より、常に唯一の解のみ存在する。

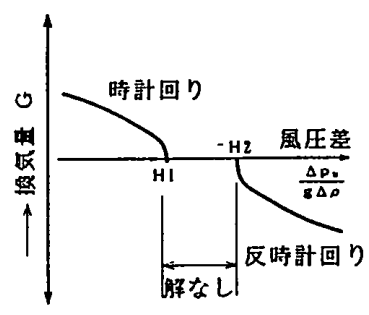

A ) $\mathrm{HI}+\mathrm{H}_{2}<0$ のとき

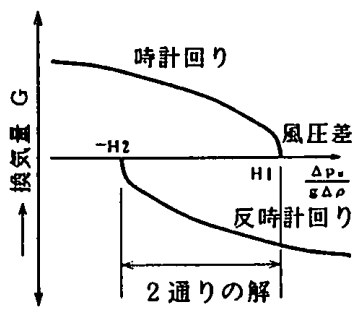

B) $\mathrm{H} 1+\mathrm{H} 2>0$ とき
図 3 室温設定の場合の換気の多様性

\section{2 全室供給熟設定の域合}

供給熱設定の場合には、室温 $\hat{\theta}$ は知数であるので、 (16)、（17)式より換気量 $G$ を消去し室温を求めれば、

$\left(\frac{T_{0}+\dot{\theta}}{T_{0}} \frac{1}{\alpha A_{1}^{2}}+\frac{1}{\alpha A_{2}^{2}}\right) \frac{\dot{Q}^{2}}{\dot{\theta}^{2}}=2 C_{,}\left(\frac{\dot{\theta}}{T_{0}+\dot{\theta}}\right) \rho_{. g} H_{1}-\Delta_{p_{W}}(21)$ $\left(\frac{1}{\alpha A_{1}^{2}}+\frac{T_{0}+\dot{\theta}}{T_{0}} \frac{1}{\alpha A_{2}^{2}}\right) \frac{\dot{Q}^{2}}{\hat{\theta}^{2}}=2 C_{,}\left(\frac{\dot{\theta}}{T_{0}+\dot{\theta}}\right) \rho_{\circ g} H_{2}+\Delta p_{W}(22)$

ここで、説明の便宜上断熱壁（ $U=0 ）$ としている。

上式はいずれも间の 5 次の多項式になり、右辺が非負 の範囲で非負の $\hat{\theta}$ の解が換気経路の多梯性を決める。

(21)、(22)式の解の例を図 4 に示す。図には $H_{1} 、 H_{2}$ の一方を左右反転して表示しており、横座標の風压差の 正負を読み替えて用いる。 $H_{1} 、 H_{2}$ はいずれも、負値 となる場合には与条件 $\Delta p w$ w対して極值を有し、二つの 解を有するか解なしのいず秃となる。二つの開口高さ に対する（唯一あるいは複数の）解は換気経路が時計回 り、反時計回りに対応する。
図 5 は $H_{1} 、 H_{2}$ の正負による換気の多様性を示す。 与条件である風圧差による図の (A) ( D )のように解の 個数が異なる。（D)では解の存在しない領域があるが、 断熱壁を有しておればこの領域では室温は無限大、換気 は零とみなせる。

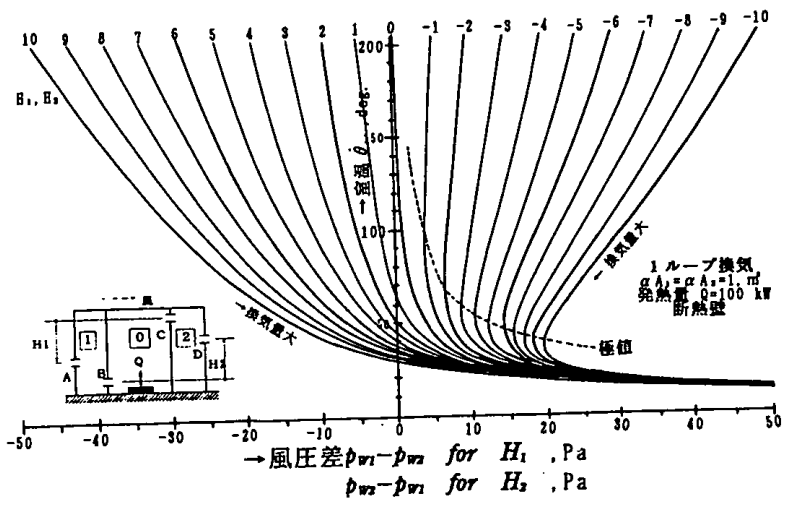

図 4 1ループ換気における風圧差と室温の関係

A ) $\mathrm{H} 1+\mathrm{H} 2<0$ のとき

B ) $\mathrm{H} 1+\mathrm{H}_{2}>0$ とき
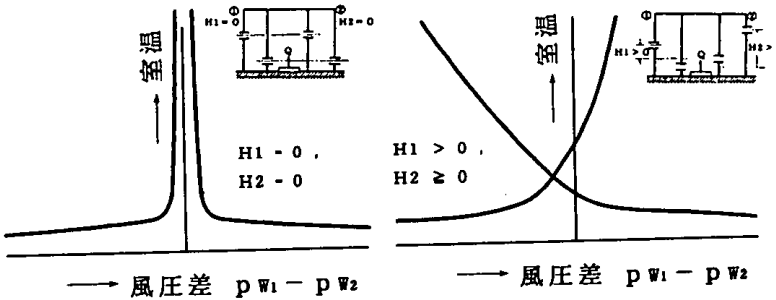

(A)風压差 0 以外で唯一解

（B）全範团で 2 つの解

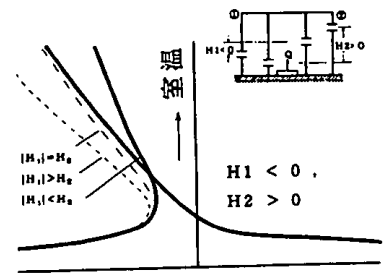

一風压差 $\mathrm{p} \mathbb{w}_{1}-\mathrm{p} \mathbf{w}_{2}$

（C） 1 つの解と 3 つの解

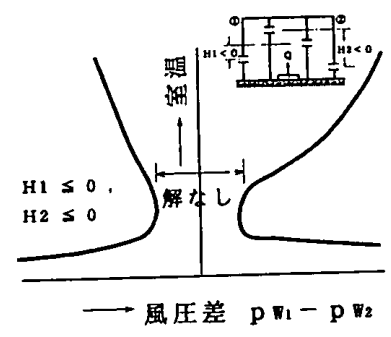

(D) 2 つの解と解のない筑柬
図 51 ループ換気における多様性

図 6 は $H_{1}=-H_{2}=2 \mathrm{~m}$ の場合についての換気計算 の例である。図は外気風圧差 $\Delta p w$ の変化に対する換気性 状の差違を示す。図には壁体熱損失のある場合も示すが、 通常の事務室程度の大きさでは熱コンダクタンスは $U$ $\leqq 200 \mathrm{kcal} / \mathrm{h} \cdot \mathrm{deg}$.であり、図に示すように、 $U$ 自体 による解の多様性存在への影響は小さい。風力換気の場

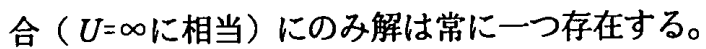

表 1 は外皮が 2 開口の風圧差 $\Delta \mathrm{pw}$ w $8 \mathrm{~Pa}$ (自由風速で約

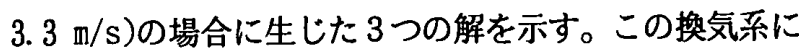
おける外部に対する「仕事」は、時計回り、反時計回り のそれぞれについて、 
表 11 ループ単空換気の多様性の例

\begin{tabular}{|c|c|c|c|c|c|}
\hline 解 & $\begin{array}{l}\text { 室温 } \\
\text { deg. }\end{array}$ & $\begin{array}{l}\text { 換気量 } \\
\mathrm{kg} / \mathrm{min}\end{array}$ & $\begin{array}{c}\text { 室内在 } \\
\mathrm{Pa}\end{array}$ & $\underset{\substack{\text { 仕事 } \\
\text { W }}}{ }$ & 換気経路 \\
\hline $\begin{array}{l}1 \\
2 \\
3\end{array}$ & $\begin{array}{r}162.8 \\
135.9 \\
41.8\end{array}$ & $\begin{array}{r}36.7 \\
-43.9 \\
-142.9 \\
\end{array}$ & $\begin{array}{r}-3.89 \\
-3.40 \\
1.01\end{array}$ & $\begin{array}{r}-12.7 \\
4.2 \\
30.1 \\
\end{array}$ & $\begin{aligned}(1) & \rightarrow(2) \\
\} & (2) \rightarrow(1)\end{aligned}$ \\
\hline
\end{tabular}

供給熱 $100 \mathrm{~kW}$, 風圧差 $8 \mathrm{~Pa}, \mathrm{H}=2 \mathrm{~m}, \alpha \mathrm{A}=1 \mathrm{~m}^{2}$, 断熱壁, 風圧係数: 0.8 (風上), -0.7 (風下)
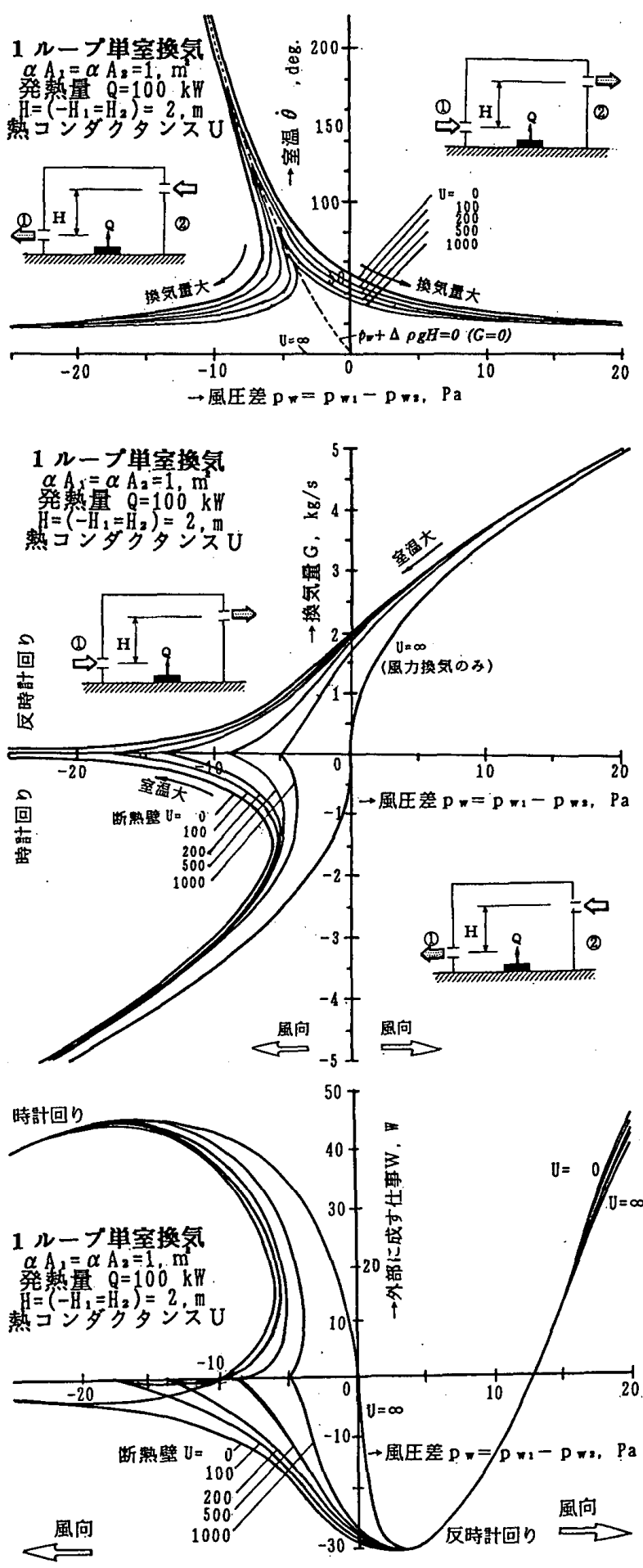

図 61 ループ単室換気での室温、換気量、仕事の変化
$\left.W=|G|\left\{+\frac{p_{w_{1}}}{\dot{\rho}}-\frac{p w_{2}}{\rho_{0}}+\frac{\dot{\rho}}{\rho_{0}} g H+\frac{1}{2}\left(\frac{G}{\dot{\rho} \alpha A_{2}}\right)^{2}\right\}\right\}_{(15)^{\prime}}$
$W=|G|\left\{-\frac{p_{w 1}}{\rho_{0}}+\frac{p w_{2}}{\dot{\rho}}-\frac{\dot{\rho}}{\rho_{0}} g H+\frac{1}{2}\left(\frac{G}{\dot{\rho} \alpha A_{1}}\right)^{2}\right\}$

室温が低いほ亡゙、言い換えれば換気量が大きい（室内 圧が外気に近い）ほど換気系の外気に戻す仕事が大きく なり、種々の外乱があったとき、表 1 の解(3)の生起する 頻度が最も大きい換気と予測される。

図 7 に示すように風圧差 $\Delta p$ wが極值を取る $p$ вより小

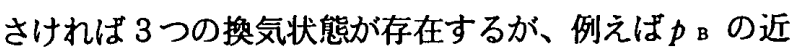
傍 $p \wedge$ から $p \mathrm{c}$ に風が変わったとすると換気は図の網掛け 部分内の線上いずれかの状態を取り得るため不安定な状 態と言えるが、外部に成す仕事の観点からは $\mathrm{A}_{1} \rightarrow \mathrm{B}_{23} \rightarrow$ $\mathrm{C}_{3}$ の線上の状態が生起頻度が高いと期待できる。

発熱量は外気風のように自然現象でなく人為的な操作 性が強く一定と見なせることが多いため発熱量の変動に 関する提示は省略する。

なお、これらの換気の多様性の存在は、室内（線形） 温度分布の存在あるいは Boussinesq 近似如何には左右さ れるものではないことを計算による試算で確かめている。

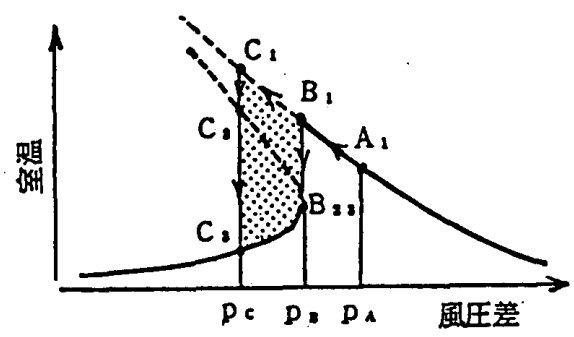

図 7 換気状態の不連続的変化

\section{6. 排煙问題における換気释路の多模性}

火災時の排煙のために設置する自然排煙口は、そこか ら確実に流出が確保されなければならないが、換気の多 様性が存在し得る条件下では、排煙口から外気が流入し 煙が意図せぬ方向に流れる危険性がある。

以下においては、自然排煙口あるいは排煙ファンを有 する換気系において、意図した換気経路む存在するが、 他の危険側の状態にもなり得る多様性の存在について、 2 室( 2 ループ)および地下 5 室 ( 5 ループ) 換気系のケ ーススタディよって示す。

\section{6-1.2ループ換気系の排煙成題}

2 閉回路で全ての開口を通ることのできる換気系を用 いて排煙口に注目した換気の多様性の問題点を述へる。

換気計算は流量仮定法により行い、各開口の換気方向 の全ての組合わせを初期条件で与え計算を行った。有効 開口面積 $\alpha \mathrm{A}$ は全て $1 \mathrm{~m}^{2}$ であり、風圧計数は風上 0.5 、 
風下-0.5、断熱壁とし、供給熱は $100 \mathrm{~kW}$ とした。 (1)自然排煙口を有する場合 :

図 8(A)は 2 室 4 開口換気での同一与条件に対して 2 個の解を持つ例である。左室天井は自然排喓口(3)が設け られているものとする。図の(A)では右室への煙の拡散 が生じ自然排煙口の効果が完璧とは言えない。（B）の方 は右室への煙の流出がみられず、排煙口が十分機能した ことになる。（15)式で定義された外部に成す仕事は(A) の方が大きく生じやすいが、排煙口としての効果は良い ものではない。

自然排煙口の効果を確実なすのにする手段は、排煙口 位置を高くするか、十分な機械排煙を行うことである。 図 8(C)(D)のように、右室開口(2)を高くした場合には、 換気の唯一解が得られる。ただし、他の条件が同じであ るとして開口(2)がある高さ（図の条件では 6.55m）を境 として開口(3)の流れが図に示すように異なる。(2)を排煙 口とするのは正しいことであるが、(3)を排煙口と設定す るためにはより高い位置の開口との関係を吟味しなけれ ば危険性のあることを示す例でもある。

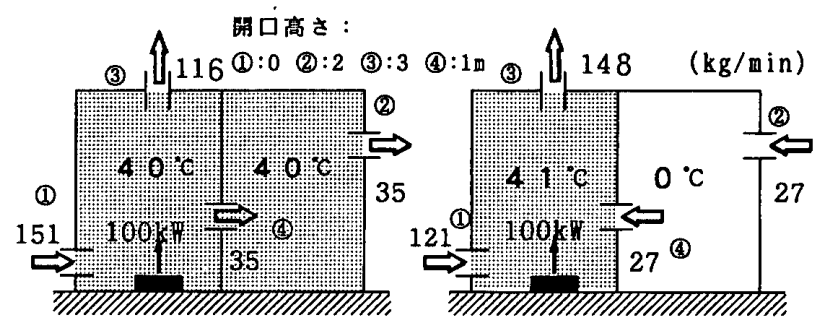

(A) 解 $1: \mathrm{W}=-71.4 \mathrm{~W}$

( B ) 解 $2: \mathrm{W}=-83.6 \mathrm{~W}$

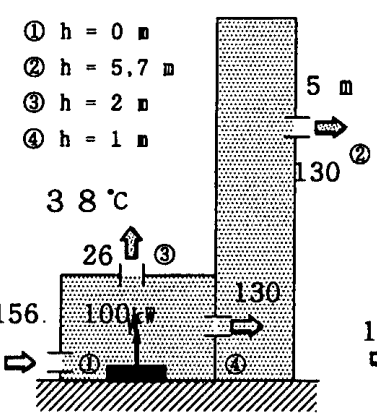

(C) 唯一解: $\mathrm{W}=-116.0 \mathrm{~W}$

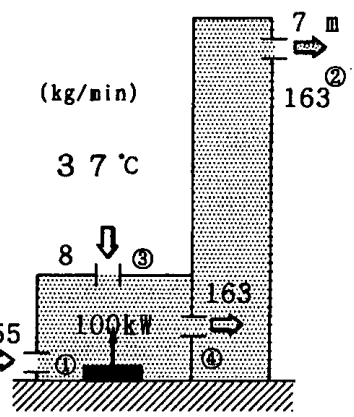

図 8 自然排煙口における換気の多様性の問題

\section{(2)排煙ファンを有する場合：}

図 9 (A)に示すように中央室に排煙ファンを設置しそ こで出火したとする。外気風によっては換気経路に多様 性が生じることを例示する。風圧差 $8 \mathrm{~Pa}$ が働くとき、 （B ） (D)の解が得られ、表 1 と同じような換気状態を 示す、 3 種類の換気が存在し得る。排煙量を増やした場 合を(E)、(F)に示すが(B)に対応した換気経路は無く、 代わりに全開口より外気を吸引する解 $(\mathrm{E})$ が得られた。

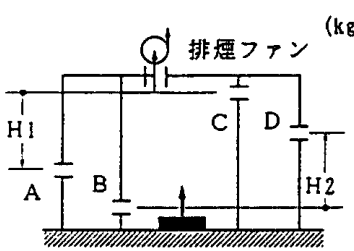

(A) 排理ファンによる換気

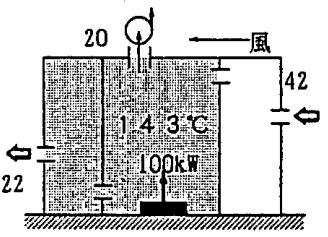

(C) 解 $2:$ 代事W $=+13.7$ 吸

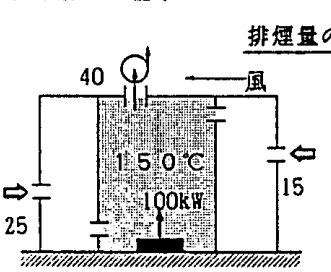

(E) 解 1: 仕事 $W=+5.1 \%$

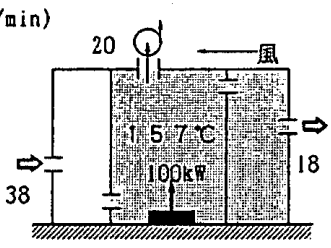

(B) 解 1: : 俚事 $W=-9.3 \%$

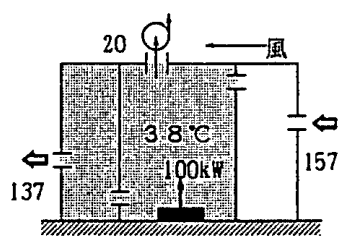

(D) 解 $3:$ 专 $W=+53.5 \%$
図 9 排煙ファンを有する換気系の多様性

図の(E)の場合が排煙ファンの効果では望ましいが、 外部に成す仕事は (F)図に比して小さくこの状態が生じ ることを期待するのは危険であり、排煙ファンを用いた としても外気風の条件によっては避難に用いられる開口 からの煙流出が生じることも考虑しなければならない。

\section{6-2. 地下室換気系の排煙问题（換気筒の効果）}

ベンチレータ（換気筒）が換気の多様性に深く関係す 例として、地下街の火災時排煙がある。出火と同時に空 調機は停止し、排煙ダクトあるいは地上との直通階段が ベンチレータの役目を成す。図 10 は防煙区画された網 目(環状) の通路と階段から成る地下街の計算モデルで ある。このモテルを用いて換気経路の多様性を検討する。

換気計算は、対称性等を考慮して、5 室を対象とし、 1〜 5 室に発熱がある場合について検討する。各室、各 開口の形状は同一とする。開口面積は全て等しくし $\alpha A$ $=1 \mathrm{~m}^{2}$ 、間仕切り高さ、外部との開口(1)（5)の高さを零 とする。ただし、ベンチレータとしての働きは $\Delta \hat{\rho} g h$

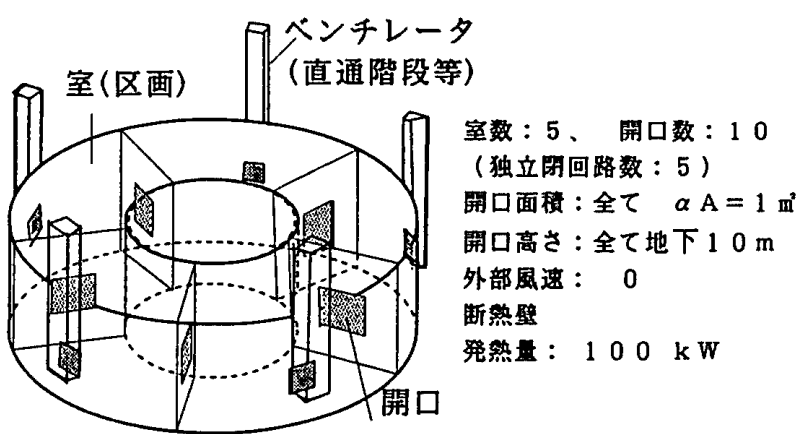

図 10 網目状換気系統 (地下街) のモデル 
によるものであるから密度差(煙流出)がある場合にのみ 高さ $(10 \mathrm{~m})$ 効果が生じる。外気風速は零。壁体は断 熱とする。発熱量設定とし各室の温度も同時に求める。

ファンによる排気が行われる場合についても計算する。

計算法としては Newton-Raphson 法を用いた流量仮定 法を用いる。 ${ }^{2)}$ 一ループ換気系のように厳密解として多 样性を見い出すことは出来ないので、逐次計算の初期の 換気経路の組み合わせを変えて複数解を求めた。

（1）地下室換気経路の多様性の例：

初期に仮定する換気方向を全ての組み合わせで計算し て収束解が幾様か得られた。図 11 は 4 通りに得られた 解を示す。(A)、(B)共に軸対称亡初期設定と解とで同 一の換気経路となった例である。図の一点鎖線は換気量 の対称軸であるが、ほとんどの計算例において換気量に （近似的な）対称軸か得られた。しかし発熱に対して対 称軸の一致する $(A)(B)$ とは別に異なる対称軸を有する (C)、（D）の解も得られる。初期換気量設定を変えた場 合も図の 4 通りのいずれかに収束した。なお図中の点線 矢印は初期設定方向で、異なる結果となった場合にのみ 図に示している。

外部に対するエネルギー $W$ の点からみると、最も想 定しやすい(A)は(C)、(D)とほほ同じ值であり、(B) のみがわずかに低い。従ってこのような地下室の 1 室で 火災が生した場合、火災室の開口がベンチレー夕の役目 をするとは限らず、煙流出の生じる開口を同定するのは 困難である。

\section{(2)外部風速の影響：}

図 12 に外部風のある場合の解を示す。図中の○の数 值は風圧係数を示す。初期経路は同一として、風速 $\mathrm{V}$ が
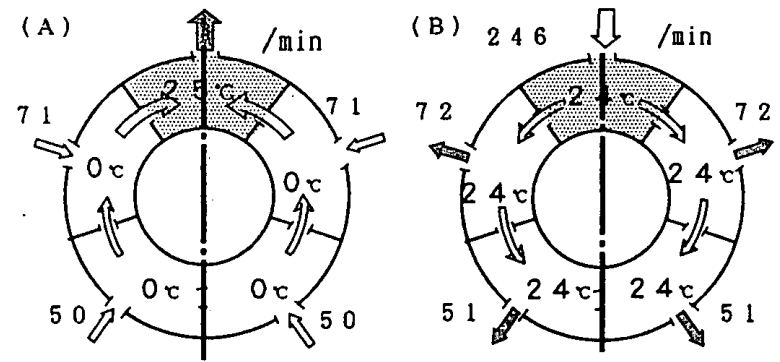

$W=-370 \%, 243 \mathrm{~kg} / \mathrm{min} W=-400 \%, 246 \mathrm{~kg} / \mathrm{min}$
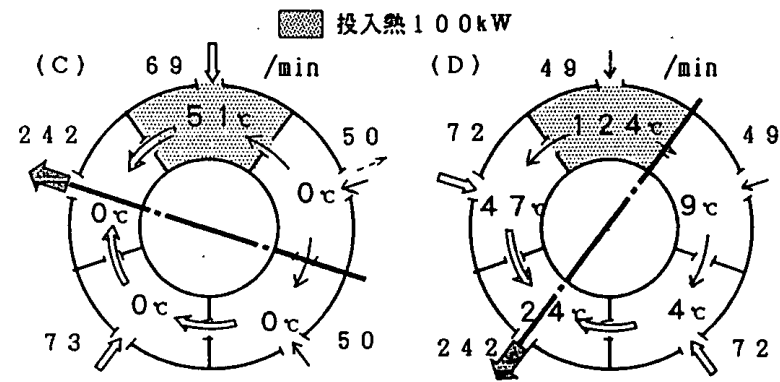

$W=-367 \%, 241 \mathrm{~kg} / \mathrm{min}$

$W=-367 w, 241 \mathrm{~kg} / \mathrm{min}$

図 11 地下室換気の多样性（無風時）

0〜 $2 \mathrm{~m} / \mathrm{s}$ の時は結果は図 11 と同様の多様性がみられ

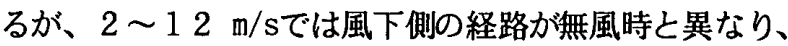
$12 \mathrm{~m} / \mathrm{s}$ 以上では初期経路の如何にかかわらず換気筒よ り発熱室への風の押し込みが見られる。

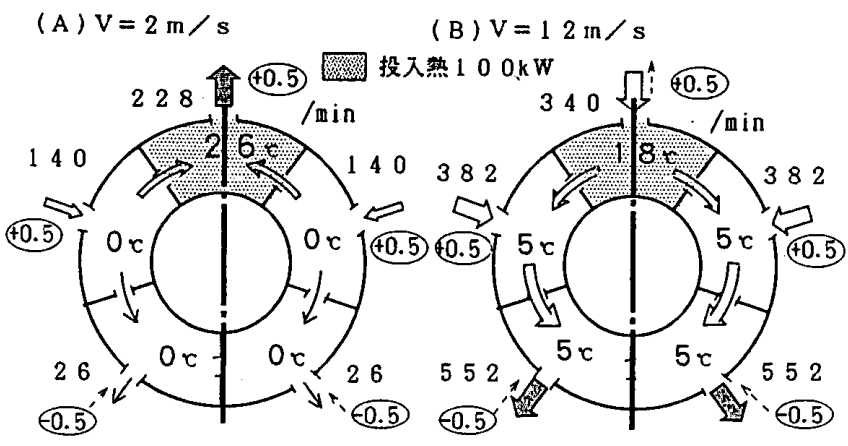

図 12 外部風速のある場合 $(2 \mathrm{~m} / \mathrm{s} 、 12 \mathrm{~m} / \mathrm{s})$

\section{(3)発熱室の分布の効果 :}

図 13 は発熱が 2、4、5室ある場合を示す。発熱 2 室の場合、その対称軸と換気量の対称軸が一致する(A)

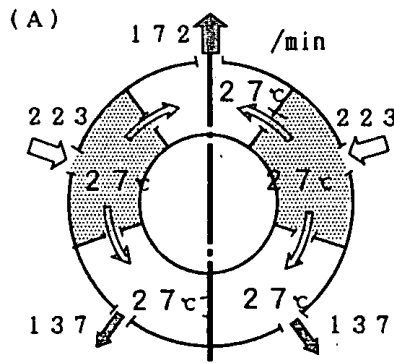

$W=-709 \mathrm{~m}, 446 \mathrm{~kg} / \mathrm{m} \mathrm{in}$

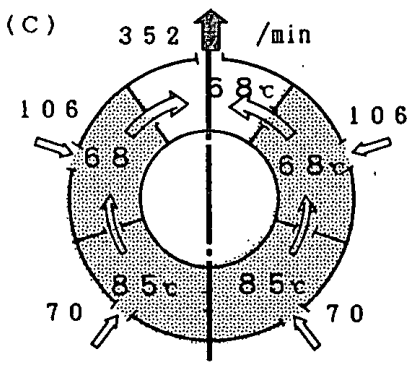

$W=-464 \%, 350 \mathrm{~kg} / \mathrm{min}$

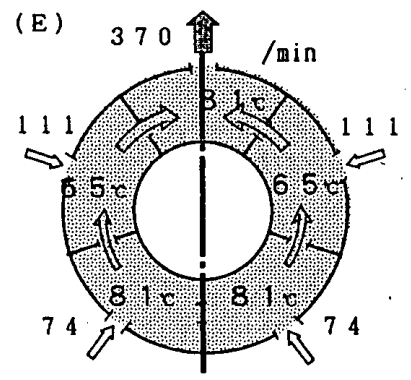

$W=-468 \mathrm{H}, 370 \mathrm{~kg} / \mathrm{min} \quad \mathrm{W}=-830 \mathrm{~W}, 574 \mathrm{~kg} / \mathrm{min}$

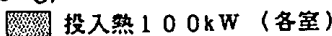

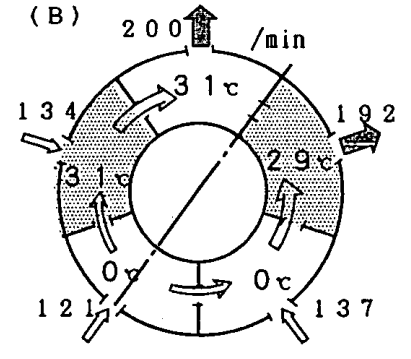

$W=-611 w, 393 \mathrm{~kg} / \mathrm{min}$

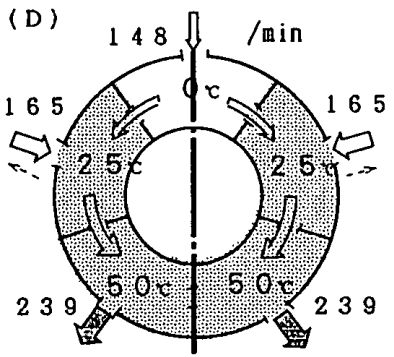

$W=-719 w, 478 \mathrm{~kg} / \mathrm{min}$

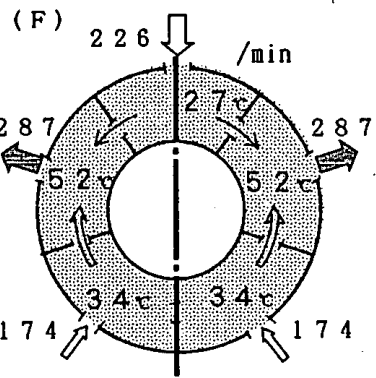

図 13 複数の発熱室の場合 
の場合もあるが、(B)のように軸が一致せず換気量の対 称性も悪い例が得られる。図示してはいないが、排気が 1 力所で他開口が全て流入となる場合も存在する。発熱 3 室の場合については 2 室発熱と同様の傾向が見られる。

図の (C)、(D)は発熱 4 室の場合を示すが、初期換気 路を如何なる組み合わせで行ってみても結果は図のいず れかの場合に一致した。外部に成す仕事から判断して （C）の場合の方が生じやすいとみられる。

図の $(\mathrm{E}) 、(\mathrm{~F})$ は全室一様発熱のある場合の計算結果 を示す。(E)は 1 力所（F)は 2 力所の排気開口がある。 (F)と全く逆の換気方向の解は得ることが出来るが(E) と全く逆の 4 力所排気の計算結果は得ることは出来なか った。（初期条件を 4 力所排気としても結果は 2 力所排 気となった。)

\section{(4)排気ファンのある場合:}

ファンによって排気した場合（圧力バランスした定風 量ファンによるものとする）を検討する。発熱室より排 気する場合は図 11 (A) と同梯の換気経路の結果のみ得 られた。発熱室以外での排気については図 14 に例示す る。図 14 (A)は発熱室からの自然排気がみられるが、 (B)の場合のように排気は近傍室への流入でほとんど賄 われるため発熱室の温度が異常に高くなる結果も得られ た。ファンを除外して外気に成す仕事は両者とも（流入 のみであるから）零であるが、ファンによる排出熱量は （A）の方が少なく、何らかの外乱があれば(A)のように 発熱室より換気筒への流出が生じることになるであろう。

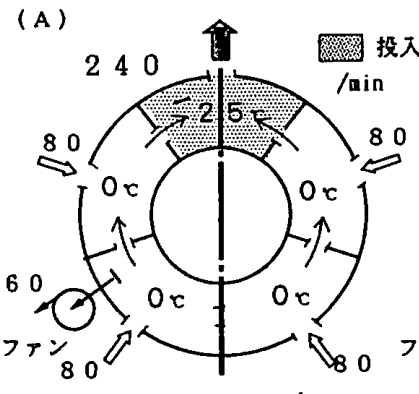

$\mathrm{W}=-367 \mathrm{~W}, 300 \mathrm{~kg} / \mathrm{min}$

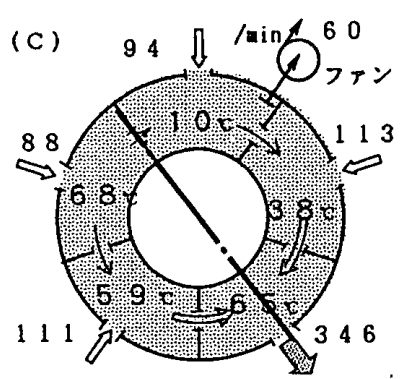

$W=-463 \mathrm{k}, 406 \mathrm{~kg} / \mathrm{min}$ 投等 $100 \mathrm{~kW}$ (各堂)

図 14 ファンによる排気がある場合
全室発熱で排気ファンを 1 力所用いた場合の結果を図 14 (C)、(D)に示す。ファン設置室が換気量の対称軸 （ただし対称性は弱い）にある場合と無い場合の二様の 結果が得られた。(C)図では多量の自然排気が他室であ り室温も低いが、(D)ではファン室で給気をほメ゙賄って おり他室での換気が少なく(B)と同粎、室温が異常に高 くなっている。外気に成す仕事量では(A)の方が大きく、 発生しやすいであろう。火災が発生しており起動してい るファン排埋量が小さければ、予期せ她の個所で多量 の煙の排出が生じる危険性が潜在する。

\section{7. 結䴝}

換気回路網における流れの経路、流量、室温について、 外気風、投入熱等の与条件によっては多様な換気状態が 生じることを、換気の一般表現の基礎式を用いて示し、 この多様な解は主として浮力換気に起因する事を示した。

同一与条件の下での複数の換気状態の生じる場合につ いては、換気系が外部に成す「仕事」（力学的エネルギ 一）が大きい状態ほど生起頻度が相対的に高いとみなし その評価指標とした。

1 閉回路で形成される換気系を用いて、換気の多様性 を厳密解にて例示し、全室温度設定の場合でも 2 種まで の換気状態があり、供給熱設定の場合は 3 種までの多様 性があることを示した。

火災時の自然排煙、機械排煙において換気の多様性が 生じることは危険性を伴う問題であり、排煙口あるいは 排煙ファンの設置について以下の 2 つの場合を検討した。

(1)排煙口が高所に設置されでも他室の開口状態によ っては効果が不十分であったり全く機能しない場合があ ることを示した。

（2）地下街のように地上との開ロがベンチレータの役 目を成すことがあり、大きな浮力がいずれの開口で働く かによって多様な換気状態が得られ避難路の確保を危う くする場合があることを、多数室換気計算により示した。

最後に、多様な換気経路を有する換気系においてより 発生しやすい状態を、外部に成す「仕事」でもって評価 するという作業仮説を立てたが、換気系の動的な解析を 含めて、不安定な換気と外部に成す「仕事」の関係の分 析を今後の課題としたい。

\section{参考文献：}

1)前田敏男、松浦邦男、換気筒の実験」、日本建築学会 研究報告集、第 19 号、1952。

2)新田勝通、「地下街機械排煙系統に関する計算法」、 日本建築学会近畿支部研究報告、1990。 